\title{
UJI COBA PETI IKAN SEGAR BERPENDINGIN UNTUK PEDAGANG IKAN KELILING
}

\section{Performance Tests of Refrigerated Fish Container for Fish Retailers}

\author{
Tri Nugroho Widianto ${ }^{1^{*}}$, Wawan Hermawan ${ }^{2}$ dan Bagus Sediadi Bandol Utomo ${ }^{3}$ \\ ${ }^{1}$ Loka Penelitian dan Pengembangan Mekanisasi Pengolahan Hasil Perikanan, Jl. Imogiri Barat Km11,5. \\ Bantul-DI.Yogyakarta, Indonesia \\ ${ }^{2}$ Institut Pertanian Bogor, Indonesia \\ ${ }^{3}$ Balai Besar Penelitian dan Pengembangan Pengolahan Produk dan Bioteknologi Kelautan dan Perikanan, \\ JI. K.S. Tubun Petamburan VI, Jakarta Pusat, Indonesia \\ * Korespondensi Penulis: trinugrohowidianto@yahoo.com
}

Diterima: 10 Maret 2014; Disetujui: 20 September 2014

\begin{abstract}
ABSTRAK
Uji coba peti ikan segar berpendingin untuk pedagang ikan keliling telah dilakukan. Percobaan diawali dengan pengamatan suhu ruang peti ikan dalam kondisi kosong (tanpa ikan) yang dilakukan tiap 10 menit selama 2 jam. Percobaan berikutnya dilakukan dengan cara pengamatan terhadap proses penjualan ikan menggunakan peti berpendingin oleh pedagang keliling selama 3 hingga 4 jam. Suhu ikan diukur tiap 10 menit, sedangkan mutu kesegaran ikan diamati pada awal dan akhir percobaan. Hasil uji coba peti dalam kondisi kosong menunjukkan bahwa suhu dapat mencapai $11,1-15,5^{\circ} \mathrm{C}$. Setelah diisi $30 \mathrm{~kg}$ ikan yang telah didinginkan hingga $0-1{ }^{\circ} \mathrm{C}$ dan dilakukan praktek penjualan ikan eceran selama 3-3,8 jam, suhu ikan mencapai sekitar $3{ }^{\circ} \mathrm{C}$ dengan nilai mutu organoleptik dan jumlah bakteri yang hampir tidak berubah. Dapat dikatakan bahwa peti ikan berpendingin mampu mempertahankan suhu dan mutu kesegaran ikan selama proses penjualan ikan eceran oleh pedagang ikan keliling.
\end{abstract}

KATAKUNCl: peti berpendingin, ikan segar, sepeda motor, pedagang ikan keliling

\begin{abstract}
Performance test of refrigerated fish container was began with the determination of temperature of the empty container during 2 hours, which was conducted every 10 minutes. The next test was conducted by observing the retailing process of fish using the refrigerated container for about 34 hours. It was revealed in this experiment that in empty condition, the temperature of the container could achieve 11.1-15.5 ${ }^{\circ} \mathrm{C}$ during 2 hours. After being loaded with $30 \mathrm{~kg}$ of fish which have been preciously iced at $0-1{ }^{\circ} \mathrm{C}$ and applied in actual practice of fish retailing, the fish temperature rose up to $3{ }^{\circ} \mathrm{C}$ after 3-3.8 hours, and almost no changes on organoleptical characteristics as well as the bacterial count of fish. It could be concluced that the refrigerated fish container could maintain the temperature and the freshness of fish during retailing practice.
\end{abstract}

KEYWORDS: $\quad$ refrigerated container, fresh fish, motorcycle, fish retailers

\section{PENDAHULUAN}

Proses pembusukan ikan dapat ditunda dengan menerapkan sistem rantai dingin yaitu mengkondisikan ikan pada suhu rendah. Pada suhu rendah aktivitas pembusukan secara kimiawi dan enzimatis dapat diperlambat. Pada penyimpanan suhu di bawah $10^{\circ} \mathrm{C}$ juga dapat menghambat pertumbuhan mikroba (Buckle 1978). SNI 01-2729.3-2013 (BSN, 2013) mensyaratkan agar penanganan ikan segar selama transportasi dan penyimpanan dilakukan pada suhu di bawah $5^{\circ} \mathrm{C}$.
Tempat penyimpanan ikan yang digunakan oleh pedagang ikan keliling selain menggunakan kotak styrofoam juga menggunakan ember plastik yang diletakkan di dalam keranjang yang terbuat dari anyaman bambu yang digantungkan di kedua sisi belakang sepeda motor. Cara seperti ini dapat menjaga keseimbangan berkendaraan, namun tidak dapat menerapkan sistem rantai dingin. Material ember plastik mempunyai nilai konduktifitas yang relatif tinggi dibanding dengan bahan insulasi lain seperti styrofoam, sehingga panas dari lingkungan akan mudah masuk ke dalam ruang penyimpanan ikan. 
Selain itu, desain alat ini juga tanpa penutup, sehingga proses perpindahan panas sangat mudah serta memicu kontaminasi pada ikan. Penggunaan kedua alat transportasi tersebut sulit untuk menerapkan sistem rantai dingin, selain itu penggunaan alat tersebut sulit diaplikasikan menggunakan sepeda motor untuk kegiatan pedagang ikan keliling.

Sistem rantai dingin dapat diterapkan dengan menambahkan es di dalam peti ikan atau menggunakan peti ikan berpendingin. Penggunaan es sebagai media pendingin banyak diaplikasikan karena mudah dan mempunyai kapasitas pendinginan yang besar (Jain et al. 2005). Kendala yang dihadapi dalam penggunaan es adalah penambahan es dapat mengurangi kapasitas peti, selain itu juga menambah bobot sehingga dapat mengganggu keseimbangan berkendaraan karena kapasitas angkut sepeda motor terbatas. Penggunaan bongkahan es yang besar dan kasar serta tajam juga akan menyebabkan kerusakan fisik ikan. Alternatif yang dapat diterapkan adalah penggunaan peti insulasi berpendingin yang menggunakan sistem pendingin untuk menjaga atau mengkondisikan suhu ikan tetap rendah. Pada penelitian ini dilakukan uji coba terhadap peti ikan segar berpendingin untuk pedagang ikan keliling menggunakan sepeda motor, yang diharapkan dapat mempertahankan mutu ikan segar.

\section{BAHAN DAN METODE}

\section{Bahan}

Bahan yang digunakan untuk uji coba alat adalah ikan baby tuna dan tongkol. Sedangkan peralatan yang digunakan dalam uji coba alat adalah peti ikan segar berpendingin yang didesain oleh Loka Penelitian Mekanisasi Pengolahan Produk Hasil Perikanan, termometer digital, timbangan, multitester dan sepeda motor. Gambar peti ikan segar berpendingin yang digunakan dalam uji coba ditunjukkan pada Gambar 1.

\section{Metode}

\section{Perangkaian peti ikan segar berpendingin}

Wadah penyimpanan ikan terdiri atas 2 kotak (masing-masing diletakkan di sebelah kiri dan kanan sepeda motor) yang mempunyai dinding luar dan dinding dalam yang terbuat dari alumunium dan insulator dari poliuretan dengan volume masingmasing kotak $33 \mathrm{~L}$. Sistem pendingin dalam wadah penyimpanan ikan menggunakan pendingin termoelektrik dengan elemen peltier dan ditambahkan heatsink dan heatpipe serta menggunakan sumber listrik dari aki sepeda motor dengan tegangan $12 \mathrm{~V}$.

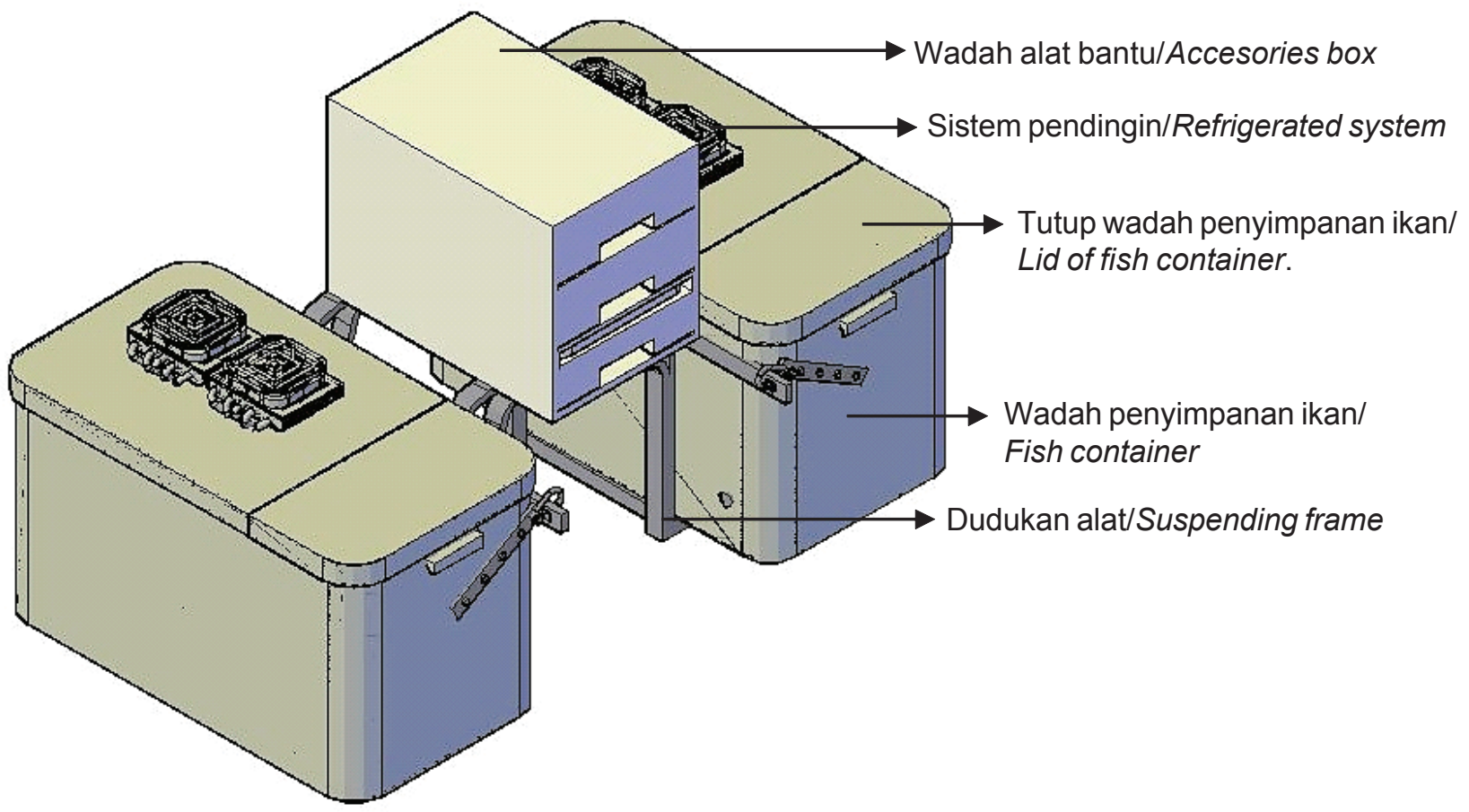

Gambar 1. Peti ikan segar berpendingin.

Figure 1. Refrigerated fish container. 
Prinsip kerja sistem pendingin ini adalah terjadinya perbedaan suhu antara sisi panas dan sisi dingin elemen peltier $(\Delta \mathrm{T})$ ketika dialiri arus listrik searah (DC). Bagian sisi dingin elemen peltier digunakan untuk menyerap panas ruang penyimpanan yang kemudian dilepas ke lingkungan melalui sisi panas elemen peltier sehingga suhu ruang penyimpanan ikan menjadi rendah. Untuk dapat mencapai suhu sisi dingin elemen peltier yang optimal, maka sisi panas elemen harus diturunkan serendah-rendahnya dengan menambahkan heatpipe untuk mempercepat proses pelepasan panas ke lingkungan. Alat ini juga dilengkapi dengan wadah alat bantu untuk tempat timbangan, pisau dan perlengkapan pedagang, sedangkan untuk meletakkan semua rangkaian tersebut di atas sepeda motor digunakan dudukan alat yang terbuat dari alumunium.

\section{Uji coba alat}

\section{Uji coba alat dalam kondisi kosong}

Pengujian dilakukan untuk mengetahui suhu ruang penyimpanan ikan yang dapat dicapai saat sistem pendingin bekerja tanpa beban ikan. Pengukuran suhu dilakukan pada ruang penyimpanan ikan dan suhu lingkungan di luar peti ikan. Pengujian dilakukan tiga kali pada kondisi suhu lingkungan yang berbeda. Pengukuran suhu dilakukan menggunakan termometer digital yang dilakukan tiap 10 menit selama 2 jam.

\section{Uji coba alat oleh pedagang ikan keliling}

Uji coba alat dilaksanakan di Desa Patuk, Kabupaten Gunungkidul. Pengujian dilakukan oleh pedagang ikan keliling dengan menggunakan peti berpendingin untuk berjualan ikan. Parameter yang diukur adalah mutu ikan sebelum dan setelah kegiatan transportasi serta suhu ikan selama transportasi. Uji coba dilakukan dua kali dengan rute perjalanan yang berbeda dengan jumlah ikan yang sama sebanyak $30 \mathrm{~kg}$ dan dengan ukuran yang sama sekitar 300500 gram/ekor. Pengujian mutu ikan dilakukan untuk mengetahui apakah alat pengangkut ikan yang telah didesain dapat mempertahankan mutu ikan selama kegiatan transportasi. Sebagai pembanding dilakukan pengujian transportasi ikan menggunakan kotak styrofoam dengan perbandingan massa ikan dengan es sebanyak 3:1 (b/b), sebagaimana biasa dilakukan oleh pedagang ikan keliling. Parameter mutu ikan yang diuji meliputi nilai organoleptik menggunakan metode SNI 2346-2011 (BSN, 2011) dengan panelis terlatih sebanyak 7 orang dan kandungan total plate count/ TPC menggunakan metode SNI 01-2332.3-2006 (BSN, 2006).

\section{HASIL DAN PEMBAHASAN}

\section{Uji Coba Alat dalam Kondisi Kosong}

Suhu ruang penyimpanan pada uji coba pertama tanpa ikan selama 120 menit mencapai $11,1^{\circ} \mathrm{C}$, pada uji coba kedua $12,4{ }^{\circ} \mathrm{C}$ dan pada uji coba ketiga 15,5 ${ }^{\circ} \mathrm{C}$. Perbedaan suhu tersebut disebabkan oleh perbedaan suhu lingkungan selama pelaksanaan uji coba. Suhu lingkungan pada uji coba pertama adalah $27^{\circ} \mathrm{C}$, uji coba kedua $30{ }^{\circ} \mathrm{C}$ dan uji coba ketiga 32 ${ }^{\circ} \mathrm{C}$. Suhu lingkungan berpengaruh terhadap banyaknya panas yang masuk dari lingkungan menuju ruang penyimpanan ikan. Semakin tinggi suhu lingkungan



Gambar 2. Suhu ruang penyimpanan ikan dalam kondisi kosong pada uji coba pertama (a), uji coba kedua (b), dan uji coba ketiga (c).

Figure 2. Temperature of fish container in empty condition at the first performance test (a), the second performance test (b) and the third performance test. 
menyebabkan semakin besar jumlah panas yang masuk sehingga suhu ruang penyimpanan yang dapat dicapai juga semakin tinggi. Hal ini yang menyebabkan suhu ruang penyimpanan pada uji coba ketiga paling tinggi. Hasil pengukuran suhu ruang penyimpanan ikan pada uji coba tanpa ikan ditunjukkan pada Gambar 2.

Suhu ruang penyimpanan ikan yang dapat dicapai paling rendah adalah $12{ }^{\circ} \mathrm{C}$ pada 1 jam pertama kemudian turun menjadi $11,1{ }^{\circ} \mathrm{C}$ pada 1 jam berikutnya. Suhu tersebut dicapai pada kondisi suhu lingkungan $27^{\circ} \mathrm{C}$. Hal itu menunjukkan bahwa peti ikan berpendingin hanya dapat digunakan untuk mempertahankan suhu ikan, bila ikan yang diangkut sudah dalam keadaan dingin. Hasil penelitian Jugsujinda et al. (2010) menunjukkan bahwa suhu ruang pendingin yang dapat dicapai dengan menggunakan termoelektrik adalah sebesar $20^{\circ} \mathrm{C}$ selama 1 jam. Perbedaan tersebut disebabkan oleh volume ruang pendingin dan jumlah termoelektrik yang digunakan berbeda. Pada penelitian ini digunakan 2 buah elemen termoelektrik dengan volume ruang pendingin sebesar $33 \mathrm{~L}$. Sedangkan pada penelitian Jugsujinda et al. (2010) digunakan 1 buah elemen termoelektrik dengan volume $21,8 \mathrm{~L}$. Salah satu cara yang dapat dilakukan untuk mengoptimalkan sistem pendingin thermoelektrik adalah mengatur jumlah tegangan (voltase) arus listrik yang melalui elemen peltier seperti telah dilakukan oleh Shen et al. (2012). Namun demikian pada penelitian ini hanya dilakukan pada tegangan $12 \mathrm{~V}$ berdasarkan pertimbangan tegangan pada aki yang digunakan oleh sepeda motor.

Suhu ruang penyimpanan ikan turun dengan cepat dari sekitar $29{ }^{\circ} \mathrm{C}$ menjadi $23^{\circ} \mathrm{C}$ pada 10 menit pertama kemudian diikuti penurunan yang lambat pada waktu berikutnya. Hal ini dipengaruhi oleh jumlah arus yang mengalir ke sistem pendingin. Arus listrik yang melewati sistem pendingin pada 10 menit pertama relatif besar dibandingkan dengan menit berikutnya, sehingga penurunan suhu ruang penyimpanan pada 10 menit pertama juga relatif lebih cepat dibandingkan dengan menit berikutnya. Jumlah arus listrik yang melalui sistem pendingin ditunjukkan pada Gambar 3. Arus listrik yang melalui sistem pendingin berkisar antara 3,1 A-3,6 A, dengan nilai yang tidak jauh berbeda antara pengujian pertama dan pengujian kedua. Jumlah arus listrik yang melalui termoelektrik berpengaruh terhadap suhu ruang penyimpanan yang dapat dicapai. Menurut Huang et al. (2000), perbedaan suhu sisi panas dan sisi dingin elemen peltier yang dapat dicapai secara teoritis merupakan fungsi dari beberapa parameter di antaranya I (arus listrik yang mengalir pada elemen peltier). Selain itu juga tergantung dari krakteristik elemen peltier seperti koefisien seebeck, tahanan listrik dan konduktifitas panas bahan termoelektrik (Zhou \& Yu, 2011). Suhu ruang penyimpanan ikan dapat diturunkan dengan memberikan arus listrik yang lebih besar serta menurunkan tahanan panas heatsink (Chein \& Chen, 2005). Penggunaan bahan termoelektrik juga dapat berpengaruh terhadap performansi pendingin sistem ini. Teknik yang digunakan untuk meningkatkan performansi pendingin termoelektrik berupa manipulasi sifat fisis bahan dengan induksi elemen tertentu, manipulasi struktur kristal dengan struktur nano, dan investigasi bahan oksida bulk baru berbasis logam oksida kobalt (Sutjahja, 2010).



Gambar 3. Arus listrik yang melewati peti ikan berpendingin pada kondisi kosong. Figure 3. Electric current of refrigerated fish container in empty condition. 


\section{Uji Coba Alat oleh Pedagang Ikan Keliling}

Uji coba pertama dilakukan melalui rute Desa Plosokerep, Widodokulon, Sambipitu, Beji, Kabupaten Gunungkidul, dengan jarak tempuh sekitar 7 km dan lama transportasi 3 jam. Uji coba kedua dilakukan melalui rute Desa Plosokerep, Widodoetan, Nglegi, Patuk dan Ngalang, Kabupaten Gunungkidul dengan jarak tempuh sekitar $10 \mathrm{~km}$ dan waktu tempuh selama 3.8 jam. Kondisi jalan pada uji coba pertama sebagian besar berbatu dan naik turun, sedangkan pada uji coba kedua sebagian besar jalan beraspal, naik turun serta berbelok-belok.

Kegiatan penjualan ikan diawali dengan kegiatan persiapan yaitu merangkai dan meletakkan peti ikan berpendingin di atas sepeda motor. Sebelum dimasukkan, ikan didinginkan dengan es pada perbandingan ikan : es sebanyak 2:1 (b/b) dalam wadah styrofoam sehingga suhu ikan mencapai 0-1 ${ }^{\circ} \mathrm{C}$. Sebanyak $30 \mathrm{~kg}$ ikan kemudian dimasukkan ke dalam ruang penyimpanan ikan, setelah itu alat pengangkut dirangkaikan dengan aki sepeda motor. Penjualan ikan dilakukan dengan berkeliling dari rumah ke rumah serta pasar. Saat ada pembeli, pembeli memilih ikan kemudian ikan terpilih ditimbang, setelah harga disepakati ikan kemudian dipotong dan isi perut diambil. Penimbangan dan pemotongan ikan dilakukan menggunakan timbangan digital dan talenan yang dilakukan di atas sepeda motor. Kegiatan pemilihan, penimbangan dan pemotongan ikan dilakukan selama 4-5 menit tiap pembeli. Setelah kegiatan penjualan ikan selesai alat pengangkut dilepas dari sepeda motor kemudian dibersihkan.

Hasil pengukuran suhu ikan selama percobaan uji coba peti ikan berpendingin untuk pengeceran ikan ditunjukkan pada Gambar 4. Suhu ikan setelah kegiatan transportasi pada uji coba pertama sebesar $3^{\circ} \mathrm{C}$ dan uji coba kedua sebesar $2,8^{\circ} \mathrm{C}$. Sedangkan suhu ikan setelah kegiatan transportasi menggunakan kotak styrofoam nilainya lebih tinggi yaitu $4,6^{\circ} \mathrm{C}$ pada pengujian pertama dan $7,7^{\circ} \mathrm{C}$ pada pengujian kedua (Gambar 5). Hal ini menunjukkan bahwa peti ikan berpendingin mampu mempertahankan suhu ikan lebih baik dibandingkan dengan kotak styrofoam. Selain adanya sistem pendingin, desain tutup peti berpendingin lebih kecil dibandingkan dengan kotak styrofoam sehingga mampu mengurangi perpindahan panas melalui tutup saat kegiatan pembukaan tutup. Terlihat dalam Gambar 4 dan Gambar 5 bahwa suhu ikan naik selama transportasi. Kenaikan suhu disebabkan jumlah beban pendinginan nilainya lebih besar dari pada energi sistem pendingin. Beban pendinginan pada ruang pendingin komersial terdiri dari beban melalui dinding, beban karena aliran udara, beban ikan, dan beban penggunaan peralatan lain (Dossat, 1981). Beban pendinginan melalui dinding peti terjadi secara konveksi antara udara dengan dinding peti dan secara konduksi melalui material dinding. Menurut Welty et al. (2004) perpindahan panas yang disebabkan konveksi melibatkan pertukaran energi antara suatu permukaan dengan fluida di dekatnya. Pada dinding insulasi, perpindahan panas secara konveksi terjadi antara permukaan dinding dengan udara yang mengalir di sekitar permukaan dinding.

Hasil perhitungan menunjukkan energi yang melalui dinding ruang penyimpanan sebesar 8,22 Watt dan panas infiltrasi udara saat kegiatan pembukaan ruang penyimpanan sebesar 3,97 Watt, sehingga panas keseluruhan adalah 12,19 Watt. Sedangkan

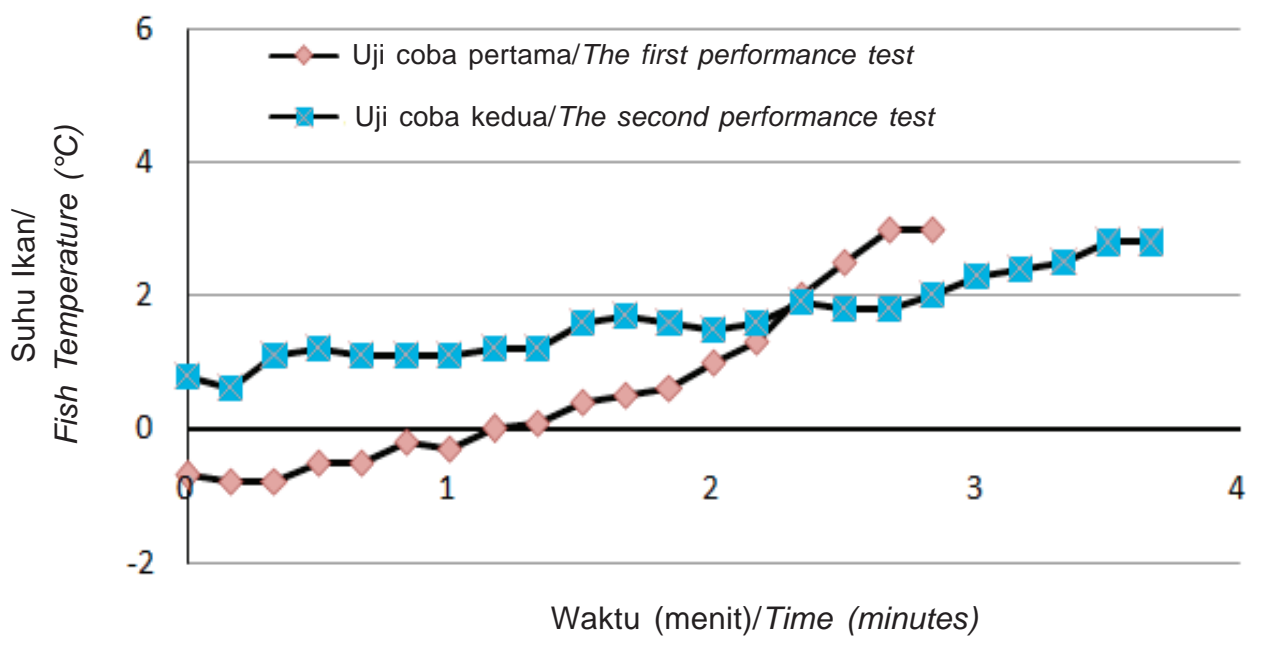

Gambar 4. Suhu ikan selama uji coba peti ikan berpendingin.

Figure 4. Fish temperature during performance test of refrigerated fish container. 


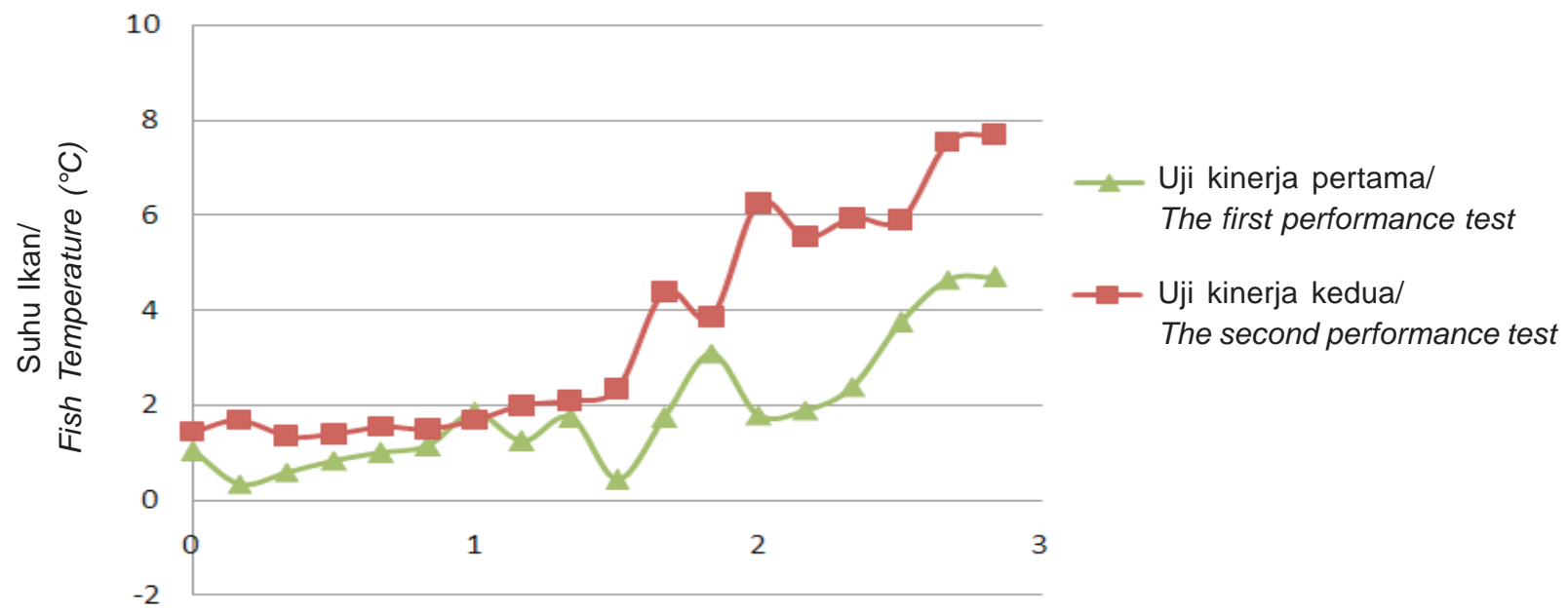

Waktu (menit)/Time (minutes)

Gambar 5. Suhu ikan selama uji coba menggunakan kotak stirofom.

Figure 5. Fish temperature during performance test used of styrofoam box.

jumlah panas yang dapat dipindahkan oleh alat pengangkut sebesar 9,67 watt, sehingga selisih panas tersebut menyebabkan kenaikan suhu ikan, namun demikian suhu akhir ikan setelah transportasi sekitar $3^{\circ} \mathrm{C}$, suhu tersebut masih di bawah suhu ikan yang dipersyaratkan yaitu di bawah $5^{\circ} \mathrm{C}$. Salah satu cara yang dapat dilakukan untuk meminimalkan beban pendinginan melalui dinding adalah menggunakan material dinding peti yang mempunyai nilai konduktifitas termal rendah seperti poliuretan, sehingga beban pendinginan yang melalui dinding tidak terlalu besar. Menurut Holman (1997) nilai konduktivitas termal dari suatu bahan menunjukkan kecepatan panas mengalir dalam bahan tersebut. Kenaikan suhu ikan pada uji coba pertama lebih cepat dibandingkan dengan uji coba kedua. Hal ini disebabkan suhu udara lingkungan pada uji coba pertama lebih tinggi dibanding dengan uji coba kedua. Suhu udara lingkungan pada uji coba pertama sebesar $32,5^{\circ} \mathrm{C}$, sedangkan kedua sebesar $30,9^{\circ} \mathrm{C}$, sehingga perpindahan panas lingkungan menuju ruang penyimpanan ikan pada uji coba pertama lebih besar dari pada uji coba kedua.

\section{Mutu Ikan}

Hasil pengujian mutu ikan menggunakan peti ikan berpendingin dapat dilihat pada Tabel 1 yang menunjukkan bahwa semua parameter mutu ikan setelah transportasi masih memenuhi persyaratan mutu ikan segar. Sedangkan hasil pengujian mutu ikan menggunakan kotak styrofoam ditunjukkan pada Tabel 2. Terlihat dalam Tabel 2 bahwa mutu ikan setelah kegiatan transportasi menggunakan kotak styrofoam pada pengujian kedua melewati batas standar mutu yang dipersyaratkan untuk parameter TPC dengan nilai organoleptik 6,9-7,0. Nilai organoleptik ikan setelah transportasi pada peti pendingin adalah 7,1 pada pengujian pertama dan 7,3 pada pengujian kedua dari nilai awal berturut-turut 7,6 dan 7,4. Kedua nilai tersebut menunjukkan ikan masih dalam keadaaan segar. Penurunan kesegaran ikan

Tabel 1. Hasil pengujian mutu ikan pada uji coba peti ikan berpendingin

Table 1. Result of fish quality at performance test of refrigerated fish container

\begin{tabular}{|c|c|c|c|c|c|}
\hline \multirow{2}{*}{$\begin{array}{l}\text { Karakteristikl } \\
\text { Characteristics }\end{array}$} & \multicolumn{2}{|c|}{$\begin{array}{l}\text { Percobaan II } \\
\text { Experiment I }\end{array}$} & \multicolumn{2}{|c|}{$\begin{array}{l}\text { Percobaan III } \\
\text { Experiment II }\end{array}$} & \multirow{2}{*}{$\begin{array}{c}\text { Standar Mutu/ } \\
\text { Quality } \\
\text { Standard }\end{array}$} \\
\hline & $\begin{array}{c}\text { Sebelum/ } \\
\text { Before }\end{array}$ & $\begin{array}{c}\text { Sesudahl } \\
\text { After }\end{array}$ & $\begin{array}{c}\text { Sebelum/ } \\
\text { Before }\end{array}$ & $\begin{array}{c}\text { Sesudahl } \\
\text { After }\end{array}$ & \\
\hline Sensori/Organoleptic & 7.6 & 7.1 & 7.4 & 7.3 & 7.0 \\
\hline TPC (gram) & $14 \times 10^{3}$ & $23 \times 10^{3}$ & $14 \times 10^{3}$ & $24 \times 10^{3}$ & $5 \times 10^{5}$ \\
\hline
\end{tabular}


Tabel 2. Hasil pengujian mutu ikan menggunakan kotak styrofoam Table 2. Result of fish quality at performance test of styrofoam box

\begin{tabular}{lccccc}
\hline \multirow{2}{*}{$\begin{array}{l}\text { Karakteristikl } \\
\text { Characteristics }\end{array}$} & \multicolumn{2}{c}{$\begin{array}{c}\text { Percobaan II } \\
\text { Experiment I }\end{array}$} & \multicolumn{2}{c}{$\begin{array}{c}\text { Percobaan III } \\
\text { Experiment II }\end{array}$} & $\begin{array}{c}\text { Standar Mutul } \\
\text { Quality } \\
\text { Standard }\end{array}$ \\
\cline { 2 - 5 } & $\begin{array}{c}\text { Sebelum/ } \\
\text { Before }\end{array}$ & $\begin{array}{c}\text { Sesudahl } \\
\text { After }\end{array}$ & $\begin{array}{c}\text { Sebelum/ } \\
\text { Before }\end{array}$ & $\begin{array}{c}\text { Sesudah/ } \\
\text { After }\end{array}$ & \\
\hline Sensori/Organoleptic & 7.0 & 7.0 & 7.0 & 6.9 & 7.0 \\
TPC (gram) & $65 \times 10^{2}$ & $3 \times 10^{3}$ & $21.5 \times 10^{2}$ & $>5 \times 10^{5}$ & $5 \times 10^{5}$ \\
\hline
\end{tabular}

pada pengujian pertama lebih besar dibandingkan dengan pengujian kedua. Hal ini diakibatkan oleh kenaikan suhu ikan selama kegiatan transportasi pada pengujian pertama yang juga lebih tinggi seperti Gambar 4, sedangkan laju peningkatan jumlah bakteri dari kedua percobaan tidak berbeda secara signifikan.

Kandungan mikroba (TPC) ikan sebelum dan setelah transportasi pada pengujian pertama berturutturut adalah $14 \times 10^{3} \mathrm{koloni} / \mathrm{g}$ dan $23 \times 10^{3} \mathrm{koloni} / \mathrm{g}$, sedangkan pada pengujian kedua berturut-turut adalah $14 \times 10^{3} \mathrm{koloni} / \mathrm{g}$ dan $24 \times 10^{3} \mathrm{koloni} / \mathrm{g}$. Kandungan TPC ikan setelah transportasi tersebut jauh lebih kecil dibandingkan dengan standar jumlah mikroba ikan segar yaitu $5 \times 10^{5} \mathrm{koloni} / \mathrm{g}$. Hal ini menunjukkan bahwa alat pengangkut dapat memperlambat pertumbuhan mikroba, sehingga kerusakan ikan yang diakibatkan oleh mikroba dapat dicegah. Hasil pengukuran terhadap suhu ikan selama kegiatan transportasi menunjukkan suhu antara 2,8 sampai 3 ${ }^{\circ} \mathrm{C}$, sehingga aktivitas dan pertumbuhan sebagian mikroba dapat diperlambat.

\section{KESIMPULAN}

Hasil penelitian menunjukkan bahwa peti ikan berpendingin dapat mempertahankan suhu ikan di bawah $3^{\circ} \mathrm{C}$ pada saat dilakukan penjualan ikan secara eceran selama 3,8 jam. Suhu peti pada uji coba dalam kondisi kosong selama 120 menit mencapai 11,1$15,5{ }^{\circ} \mathrm{C}$. Nilai organoleptik ikan setelah kegiatan transportasi adalah 7,1-7,3, sedangkan nilai TPC adalah $23 \times 10^{3}-24 \times 10^{3} \mathrm{koloni} / \mathrm{g}$. Nilai TPC dan organoleptik ikan setelah transportasi memenuhi standar mutu ikan segar, hal ini menunjukkan bahwa peti ikan segar berpendingin dapat mempertahankan mutu ikan segar selama proses penjualan ikan secara eceran.

\section{DAFTAR PUSTAKA}

[BSN] Badan Standardisasi Nasional. (2006). Cara Uji Kandungan TPC pada Produk Perikanan. SNI 01-
2332.3.2006. Dewan Standardisasi Nasional. Jakarta.

[BSN] Badan Standardisasi Nasional. (2011). Petunjuk pengujian Organoleptik dan atau Sensori pada Produk Perikanan. SNI 2346.2011. Dewan Standardisasi Nasional. Jakarta.

[BSN] Badan Standardisasi Nasional. (2013). Ikan Segar. SNI 2729. 2013. Dewan Standardisasi Nasional. Jakarta.

Buckle, K.A., Edwards, R.A., Fleet, G.H., \& Wooton, M. (1978). Food Science. Penerjemah: Purnomo, H. dan Adiono. 1988. Jakarta.

Chein, R., \& Chen, Y. (2005). Performance of thermoelectric cooler integrated with microchanel heat sinks. International Journal of Refrigeration. 28: 828-839.

Dossat, R.J. (1981). Principles of Referigation. New York. Holman, J.P. 1997. Perpindahan Kalor. Terjemahan. Edisi keenam. Penerbit Erlangga.

Huang, B.J., Chin, C.J., \& Duang, C.L. (2000). A design method of thermoelectric cooler. International Journal of Refrigeration. 35: 208-218.

Jain, D., \& Ilyas, S.M. (2005). Development of mathematical model for cooling. Journal of food engineering. 71(25).

Jugsujinda, S., Vora-ud, A., \& Seetawan, T. (2010). Analyzing of thermoelectric refrigerator performance. Procedia Engineering. 8(154).

Shen, L.M., Xiao, F., Chen, H.X., \& Wang, S.W. (2012). Numerical and experimental analysis of transient supercooling effect of voltage pulse on thermoelectric element. International Journal of Refrigeration. 35: 1156-1165

Sutjahja, I.M. (2010). Penelitian bahan termoelektrik bagi aplikasi konversi energi di masa mendatang. Jurnal Material dan Energi Indonesia. 1(58).

Welty, J.R., Wicks, C.E., \& Rorrer, G.L. (2004). DasarDasar Fenomena Transport. Terjemahan. Penerbit Erlangga. Edisi keempat. Jakarta.

Zhou, Y., and Yu, J. (2011). Design optimization of thermoelectric cooling systems for applications in electronic devices. International Journal of Refrigeration. 35: 1139-1144. 